\title{
Association between hypovitaminosis D3 and type II diabetes mellitus of Iraqi patients
}

\author{
Shaymaa M. Hadi', Fadhil J. Al-Tu'ma², Riyadh D. Al-Zubaidi³
}

\author{
'Department of Pharmaceutical Chemistry, College of Pharmacy, University of Kerbala, Kerbala, Iraq. \\ 2Department of Chemistry and Biochemistry, College of Medicine, University of Kerbala, Kerbala, Iraq. \\ ${ }^{3}$ Department of Internal Medicine, College of Medicine, University of Kerbala, Kerbala, Iraq \\ Correspondence to: Shaymaa M. Hadi (shaymaa.hadi88@gmail.com) \\ (Submitted: 18 April 2020 - Revised version received: 07 May 2020 - Accepted: 14 June 2020 - Published online: 26 June 2020)
}

\begin{abstract}
Objective This research has been carried out to evaluate the levels of 25-hydroxy vitamin D3 ([25(OH)D3]) as well as the correlation between the deficiency levels with the risk of experiencing type 2 diabetic mellitus (T2DM) in sample of Iraqi population.

Materials and Methods The levels regarding the [25(OH)D3] and the fasting blood sugar (FBG) have been estimated in group of 58 T2DM patients and 31 control subjects of age between 25 and 65 years. The [25(OH)D3] has been estimated via ELISA and FBG was measured spectrophotometrically.

Results The levels of [25(OH)D3] have been considerably lower in individuals experiencing T2DM $(9.465 \pm 3.567 \mathrm{ng} / \mathrm{ml})$ than in the control group $(14.146 \pm 11.045 \mathrm{ng} / \mathrm{ml})$, $(p=0.02)$, whereas FBG levels were considerably higher in patients experiencing T2DM (218 $\pm 66 \mathrm{mg} / \mathrm{dl})$ widespread in comparison to control group $(89.8 \pm 9 \mathrm{mg} / \mathrm{dl}),(p=0.009)$. The levels related to the $[25(\mathrm{OH}) \mathrm{D} 3]$ are inversely related to FBG in both diabetic and control group $\left(p=0.01, r^{2}=0.1\right),\left(p<0.01, r^{2}=0.2\right)$, respectively. Vitamin D3 deficiency (VDD) is considered to be related to the hazard of experiencing T2DM; also it is highly prevalent in subjects of Iraqi nationality.

Conclusion VDD is associated to the risk of experiencing T2DM. Hypovitaminosis D is very prevalent among the study participants and its percent was higher in female and have a therapeutic implications as cautious supplementation of vitamin D could enhance glycemic control in T2DM.

Keywords Hypovitaminosis D, 25-hydroxyvitamin D3, 25(OH)D3, Type Il diabetes mellitus, T2DM, 25-hydroxy vitamin D3.
\end{abstract}

\section{Introduction}

Type 2 diabetes is related to considerable morbidity and mortality all over the world. Interactions between factors of genetics and environment, which include diet, have an important impact on the development of this condition. ${ }^{1-3}$ Over the last decade, accumulating evidence has indicated that the concentration of 25-hydroxy vitamin D3 ([25(OH)D3]) in the blood is inversely proportional with diabetes mellitus, hypertension and some other diseases. ${ }^{4}$ Most of the required cholecalciferol or vitamin D3 is derived from the biosynthetic pathway under the skin from 7dehydrocholesterol through exposure to sunlight. ${ }^{5}$

Most experts recommend an optimal concentration greater than $30 \mathrm{ng} / \mathrm{ml}$ in serum and vitamin D3 deficiency is less than $30 \mathrm{ng} / \mathrm{ml}$. Vitamin D3 deficiency is even more prevalent among patients with type 2 diabetes mellitus (T2DM), endothelial dysfunction predicts cardiovascular events and represents an essential event for vascular abnormalities observed in T2DM patients. ${ }^{6}$ Vitamin D3 [25(OH) D3] has numerous biological actions, like calcium homeostasis and metabolism, stimulation of the innate immune response, maintaining of blood glucose level, and insulin secretion stimulation in order to therapeutically use it in diabetics. ${ }^{7}$ There is a relation between diabetes mellitus and vitamin D3 deficiency (VDD) as well as a relation with cancer, dyslipidemia, endothelial dysfunction, and hypertension. ${ }^{8}$ It was observed that the estimation of $25(\mathrm{OH}) \mathrm{D}_{3}$ insufficiency and deficiency is experienced by 1 billion people and its impact on abnormal metabolism of glucose as well as in diabetes type 2 was exhibited. ${ }^{9}$ Inadequate concentrations related to the circulating $25(\mathrm{OH}) \mathrm{D}_{3}$ are related to metabolic syndrome, insulin resistance (IR), glucose intolerance, and increased diabetes risk ${ }^{10}$ due to the fact that there are many indications related to the VDD may possibly have contributing impact on developing type 2 diabetes. Initially, the pancreatic beta cells has enzyme of $1 \alpha$-hydroxylase and vitamin $\mathrm{D}$ receptor $(V D R)$ and the other indication implies that treating with vitamin $\mathrm{D}$ improves IR and glucose tolerance. ${ }^{11}$ Also, it has been shown that vitamin D moderates the glycolytic pathway, stimulates the general activation regarding the protein synthesis in pancreatic $\beta$-cells, improves $\mathrm{Ca}^{+2}$ influx to $\beta$-cells in addition to promoting converting pro-insulin to insulin. ${ }^{12}$ The VDD is considered to be related to decreased release of insulin, IR, and type 2 diabetes, with regard to epidemiological and experimental researches, for example, many studies of animals showed that $1 \alpha, 25$-dihydroxy vitamin $\mathrm{D} 3\left(1,25(\mathrm{OH})_{2} \mathrm{D}_{3}\right)$ promote pancreatic $\beta$-cell in secreting insulin. The association between IR and VDD might begin from inflammation, as VDD is related to increased inflammation markers. Moreover, genetic polymorphisms of genes that are related to vitamin D could impact impaired glycemic control and diabetes of type $2 .{ }^{13}$

A direct advantageous influence related to vitamin $\mathrm{D}$ on insulin action was approved by an insulin receptors increment after $24 \mathrm{~h}$ of treatment through the use of $1,25(\mathrm{OH})_{2} \mathrm{D}_{3}$ in U-937 cells of human promonocytic. ${ }^{1}$ In addition, gathering evidence from experimental researches have suggested that activation of VDR could increase the secretion of insulin and improve insulin sensitivity, so VDD was linked to diabetes mellitus onset and progression. ${ }^{14}$ Many observational studies confirmed an association of the deficiency of 25(OH) D3 with diabetes of type 2 and disturbed glucose metabolism. On the other hand, was considerably unsuccessful in showing good [25(OH)D3] impacts on metabolism of glucose and therefore, it is still not clear whether or not $25(\mathrm{OH}) \mathrm{D} 3$ is relevant for the pathogenesis of diabetes of type 2 , so this study will clarify 
the existence of an association between T2DM and VDD as well as estimating the levels of $25(\mathrm{OH}) \mathrm{D} 3$ among the study participants.

\section{Materials and Methods}

Eighty-nine Iraqi individuals (58 T2DM cases and 31 controls) of age ranged between 25 and 65 years (male and female) have taken part in this case control study. Patients that have type 2 diabetes mellitus disease have been appointed from Al-Hussein Teaching Hospital, Al-Hussein Medical City/ Kerbala Health Directorates between April 2018 and March 2019 and diagnosed according to Criteria of American Diabetes Association (2014) defining diabetes as (FBG $\geq 126$ $\mathrm{mg} / \mathrm{dL}$ ). Healthy subjects that didn't match the standards which are used to select T2DM were assigned as control. The levels related to $\mathrm{FBG}$ and $25(\mathrm{OH}) \mathrm{D}_{3}$ have been estimated for all the participants in this research. The levels of $[25(\mathrm{OH})$ D3] have been estimated via enzyme-linked immunosorbent assay (ELISA), FBG was measured spectrophotometrically. Demographic information, medical history and past family were recorded to every participating subject. Those with comorbidities have been excluded from the study, which has been permitted via the Clinical Research Ethics Committee of the College of Medicine, University of Kerbala. The data were presented either by mean \pm standard deviation (Mean \pm SD) or ratio or percent. The $t$-test of the student has been utilized for comparing the difference between the groups of patients and controls from numerical variables. Analysis of regression has been carried out for analyzing the correlation between levels of FBG and 25(OH) D3. A chi-squared test has been carried out for comparing the number of individuals that have insufficiency and VDD in control and patients groups. In all statistical analysis, the significance value was $<0.05$.

\section{Results}

Levels of FBG have been higher in patients group having T2DM in comparison to control group, levels of FBG are (218 $\pm 66 \mathrm{mg} / \mathrm{dl})$ and $(89.8 \pm 9 \mathrm{mg} / \mathrm{dl})$ in the group of patients and group of controls, respectively $(p<0.01)$. In patients' group that have T2DM, the levels of $25(\mathrm{OH}) \mathrm{D} 3$ have been lower

\begin{tabular}{|c|c|c|c|}
\hline Parameters & $\begin{array}{l}\text { Controls } \\
\text { Mean } \pm \text { SD } \\
\mathrm{N}=31\end{array}$ & $\begin{array}{l}\text { T2DM subjects } \\
\text { Mean } \pm \text { SD } \\
\mathrm{N}=58\end{array}$ & $P$-value \\
\hline No. (M/F) & $31(15 / 16)$ & $58(28 / 30)$ & 0.9 \\
\hline Age, year & $42.6 \pm 1.9$ & $46.13 \pm 1.3$ & 0.1 \\
\hline FBG (mg/dl) & $89.5 \pm 1.8$ & $229.7 \pm 9.8$ & $<0.01$ \\
\hline 1,25(OH)D3 (ng/ml) & $14.14 \pm 1.1$ & $9.46 \pm 0.46$ & $0.02^{\prime \prime}$ \\
\hline
\end{tabular}

compared to the levels in the group of controls, the levels of $25(\mathrm{OH}) \mathrm{D} 3$ were $9.465 \pm 3.567 \mathrm{ng} / \mathrm{ml}$ and $14.146 \pm 11.045 \mathrm{ng} /$ $\mathrm{ml}$ in the group of patients and the group of controls, respectively $(p=0.02)$ as seen in (Table 1 ).

General observation to Table 2A showed that patient had greater percent of VDD in comparison with control group (100\% vs $87 \%)$, respectively. While the remaining of control group $9,68 \%$ had insufficiency of vitamin D (VDI) and only $3.23 \%$ had optimum level of vitamin D (VO). With regard to the patient group, $0 \%$ of $\mathrm{VI}$ and $\mathrm{VO}$ is recorded.

Generally, $95.5 \%$, of all population whose serum $25(\mathrm{OH})$ D3 was measured experienced VDD, 3.4\% experienced VI and $1.1 \%$ experienced VO level. Also, it has been shown that female had larger percent of VDD $(51.7 \%, 48.4 \%)$ than male $(48.3 \%, 38.7 \%)$ in both patient and control group respectively.

Because most study subjects experienced VDD, they have been subclassified into mild, moderate, and severe, and it is found that patient group had a greater percent of severe and moderate VDD $(13.8 \%, 44.8 \%)$, respectively in comparison with the control group which had only $3.7 \%, 25.9 \%$ in an order. For mild VDD, patients also had large percent (41.38\%), but it is not the greater one because the control group had it $70 \%$ as seen in Table $2 \mathrm{~B}$.

After performing the analysis in the whole population of the study, patients with T2DM and controls, 25(OH)D3 levels were discovered to have inverse association with FBG levels in the patients' group that had type 2 diabetes $(p=0.01, r=$ 0.1 , analysis of linear regression) (Fig. 1) and in control group $\left(p<0.01, r^{2}=0.22\right)$ (Fig. 2).

Table 2. Comparison of serum vitamin D status among the research subjects.

\begin{tabular}{|c|c|c|c|c|c|c|c|c|}
\hline \multirow[b]{2}{*}{$\begin{array}{l}\text { Vitamin D } \\
\text { Status } \\
\mathrm{N}=89\end{array}$} & \multicolumn{3}{|c|}{ Case } & \multicolumn{3}{|c|}{ Control } & \multicolumn{2}{|c|}{ Total } \\
\hline & $\begin{array}{l}\text { Male } \\
\text { Frequency } \\
(\%)\end{array}$ & $\begin{array}{l}\text { Female } \\
\text { Frequency } \\
(\%)\end{array}$ & $\begin{array}{l}\text { Total } \\
\text { Frequency } \\
(\%)\end{array}$ & $\begin{array}{l}\text { Male } \\
\text { Frequency } \\
(\%)\end{array}$ & $\begin{array}{l}\text { Female } \\
\text { Frequency } \\
(\%)\end{array}$ & $\begin{array}{l}\text { Total } \\
\text { Frequency } \\
(\%)\end{array}$ & Frequency & $\%$ \\
\hline $\begin{array}{l}\text { Vitamin D } \\
\text { Deficiency (VDD) }\end{array}$ & $\begin{array}{l}28 \\
(48.3)\end{array}$ & $\begin{array}{l}30 \\
(51.7)\end{array}$ & $\begin{array}{l}58 \\
(100)\end{array}$ & $\begin{array}{l}12 \\
(38.7)\end{array}$ & $\begin{array}{l}15 \\
(48.4)\end{array}$ & $\begin{array}{l}27 \\
(87.1)\end{array}$ & 85 & 95.5 \\
\hline $\begin{array}{l}\text { Vitamin D } \\
\text { insufficiency } \\
\text { (VIS) }\end{array}$ & - & - & - & $\begin{array}{l}2 \\
(6.45)\end{array}$ & $\begin{array}{l}1 \\
(3.225)\end{array}$ & $\begin{array}{l}3 \\
(9.675)\end{array}$ & 3 & 3.4 \\
\hline $\begin{array}{l}\text { Vitamin D } \\
\text { Optimum, (VO) }\end{array}$ & - & - & - & $\begin{array}{l}1 \\
(3.225)\end{array}$ & - & $\begin{array}{l}1 \\
(3.225)\end{array}$ & 1 & 1.1 \\
\hline Total & 58 & & & 31 & & & 89 & $P=0.019$ \\
\hline
\end{tabular}

* Serum vitamin D status based on US Endocrine Society classification (22).

Insufficiency $21-29 \mathrm{ng} / \mathrm{ml}$, Deficiency $\leq 20 \mathrm{ng} / \mathrm{ml}$, Sufficiency $\geq 30 \mathrm{ng} / \mathrm{ml}$. 
Table 2B. Subclassification and comparison of VDD amongst study participants.

\begin{tabular}{|c|c|c|c|c|c|c|}
\hline \multirow{2}{*}{$\begin{array}{l}\text { Vitamin D Deficient, (VDD) } \\
\mathrm{N}=85\end{array}$} & \multicolumn{2}{|c|}{ Case } & \multicolumn{2}{|c|}{ Control } & \multicolumn{2}{|c|}{ Total } \\
\hline & Frequency & $(\%)$ & Frequency & (\%) & Frequency & $(\%)$ \\
\hline Mild & 24 & (41.38) & 19 & (70.38) & 43 & 50.6 \\
\hline Moderate & 26 & $(44.82)$ & 7 & (25.92) & 33 & 38.8 \\
\hline Sever & 8 & (13.8) & 1 & (3.7) & 9 & 10.6 \\
\hline Total & 58 & & 27 & & 85 & 100 \\
\hline
\end{tabular}

${ }^{*}$ A deficiency in vitamin was sub classified to mild VDD (10-20 ng/ml), moderate

$\operatorname{VDD}(5-10 \mathrm{ng} / \mathrm{ml})$, severe $(<5 \mathrm{ng} / \mathrm{ml})(23)$.

\section{Discussion}

Several studies associated between the deficiency of 25- $(\mathrm{OH})$ D3 and various clinical conditions of Iraqi patients have been studied including hyperthyroidism, unstable angina, coronary artery diseases, and T2DM. ${ }^{8,15,16}$ The main goal of the presented research has been investigating the relation between T2DM and VDD. In this research, lower 1,25(OH), D3 levels have been noticed in patient that have T2DM compared to a control group and an inverse correlation has been noticed between levels of FBG and $1,25(\mathrm{OH})_{2} \mathrm{D} 3$ in T2DM group, which implies that the $1,25(\mathrm{OH})_{2} \mathrm{D} 3$ levels have an impact on glucose control in T2DM. In addition to that, an inverse correlation has been discovered between FBG and vitamin D levels in the entire study population, patients who have T2DM and controls when they have been examined together. It has appeared that vitamin $\mathrm{D}$ could be related with glucose control in T2DM. Moreover, from a statistically significant perspective, more subjects experiencing T2DM had vitamin D insufficiency and deficiency in comparison to control population.

Vitamin D, which is secosteroid synthesized in skin via the action of UV sun irradiation, is associated with bone metabolism. Extra skeletal impacts related to vitamin D are presently a topic of interest for researchers. ${ }^{17}$ The association of immune system and vitamin D is under an intense discussion. It has been proved that vitamin $\mathrm{D}$ stimulates the immune tolerance, VDD is related with certain autoimmune diseases, like multiple sclerosis, rheumatoid arthritis, and T1DM. ${ }^{18-21}$ The correlation between T2DM and vitamin D and metabolic syndrome is recently under a debate. Vitamin D has exhibited a relation with glucose metabolism and the progression of T2DM and the metabolic syndrome..$^{22,23}$

In a cross-sectional study to sample of population from eastern Finland, an inverse correlation has been noticed between levels of [25(OH)D3] and FBG, fasting insulin, and $2 \mathrm{~h}$ glucose tolerance tests, ${ }^{24}$ which have implied that low level of serum [25(OH)D3] could have an association with reduced metabolism of glucose. In one of the recent studies, an inverse correlation of IR with the levels of [25(OH)D3] has been noticed that has been mainly found at levels of [25(OH)D3] in the range of $16-36 \mathrm{ng} / \mathrm{ml} .{ }^{25} \mathrm{In}$ one of the nested case-control studies that have been carried out amongst 608 females with recently identified diabetes type 2 , higher concentration of plasma [25(OH)D3] was related to a lower risk of diabetes

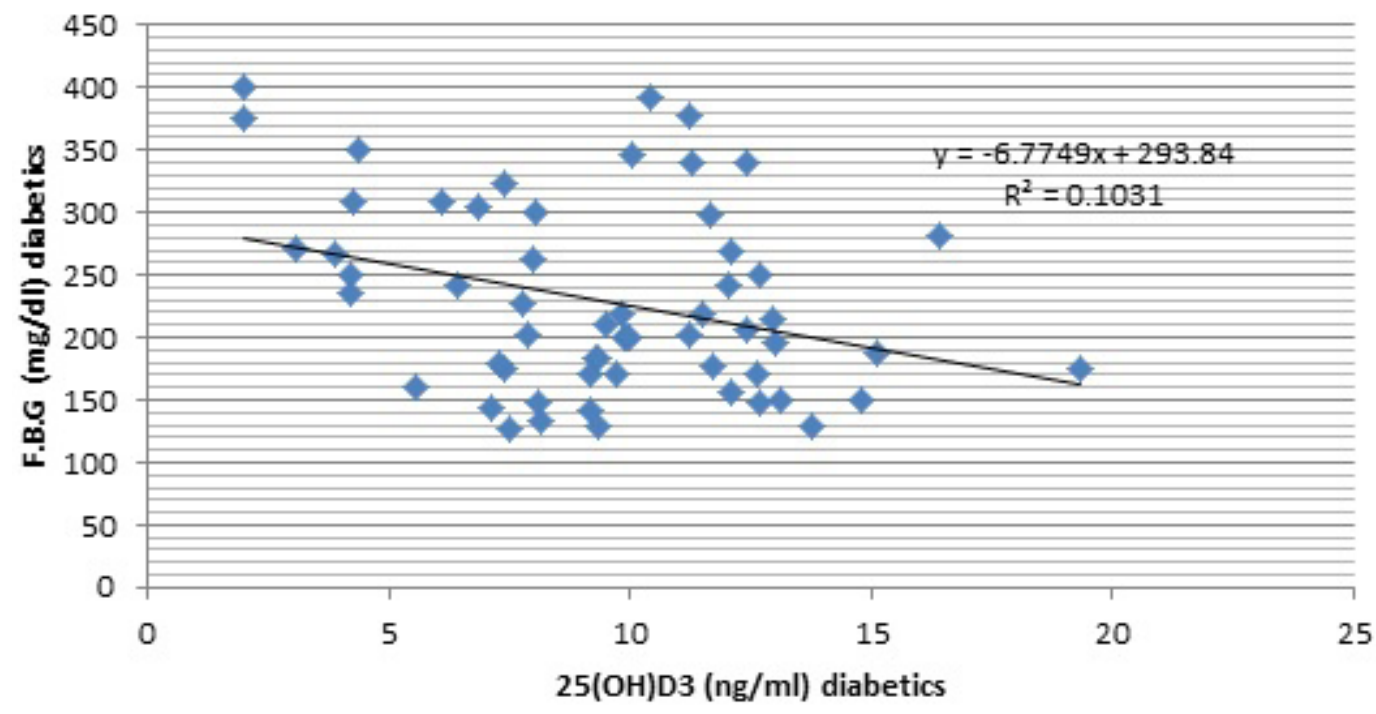

Fig. 1 Inverse correlation between FBG (mg/dl) and 25(OH)D3 $(\mathrm{ng} / \mathrm{ml})$ in subjects experiencing T2DM, $\left(p=0.01, r^{2}=0.1\right.$, analysis of linear regression). $25(0 H) D 3 ; F B G$. 


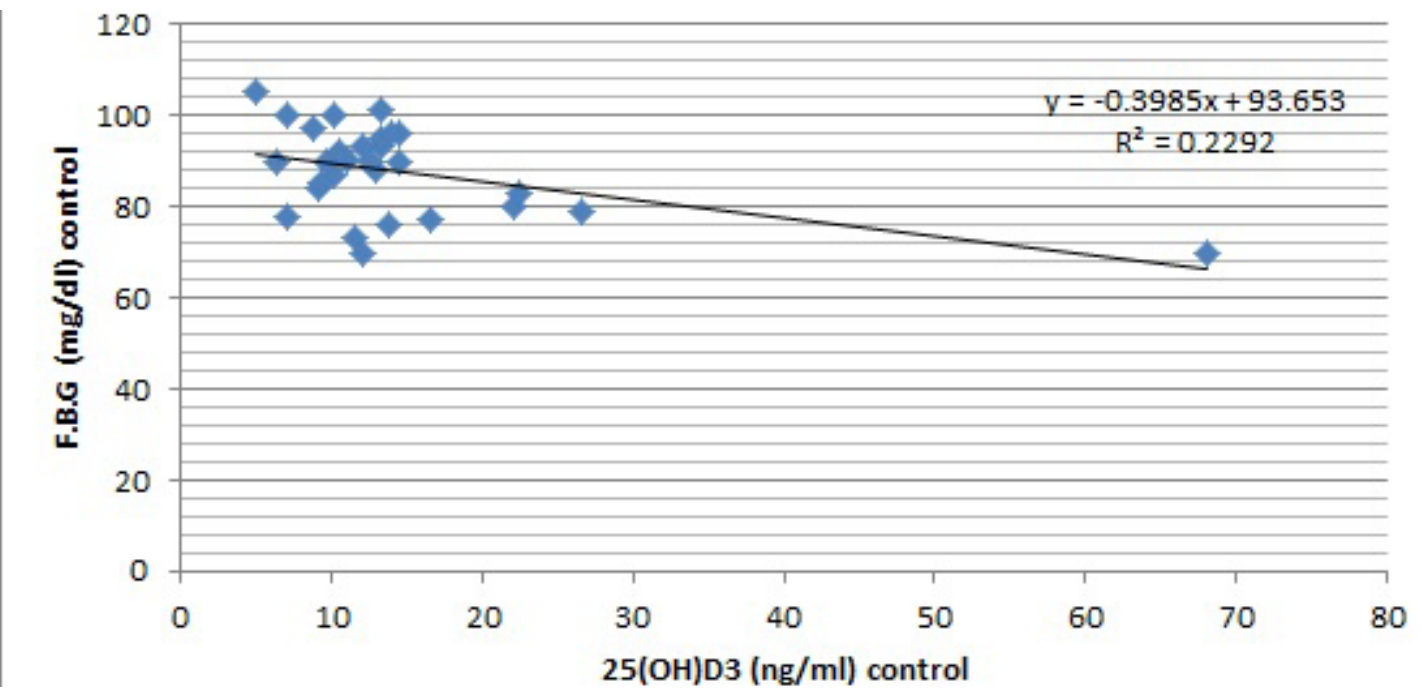

Fig. 2 Inverse correlation between FBG ( $\mathrm{mg} / \mathrm{dl})$ and $25(\mathrm{OH}) \mathrm{D} 3(\mathrm{ng} / \mathrm{ml})$ in controls $\left(p<0.01, \mathrm{r}^{2}=0.229\right.$, analysis of linear regression). 25(OH)D3; FBG.

type 2 in females. ${ }^{26}$ In a potential observational research with an average follow up of 2.7 years, higher plasma [25(OH)D3] has been related to lower risks of occurrence of diabetes in high-risk subjects. ${ }^{27}$ In a potential research in high-risk Asian individuals, deficiency of [25(OH)D3] has been related with higher risks of developing diabetes mellitus of type 2. In a longitudinal research of IR determinants and metabolic syndrome, a considerable inverse correlation of baseline $[25(\mathrm{OH})$ D3] with fasting glucose at follow-up has been recorded. In a massive group research of older individuals that involved 7791 individuals, that were at first diabetes-free, levels of serum [25(OH)D3] have been inversely related to incident diabetes in females but not in males. ${ }^{28}$

Earlier researches indicated that low vitamin $\mathrm{D}$ ingestion might be associated to higher hazard of developing the metabolic syndrome and T2DM. ${ }^{29,30}$

In one of the earlier studies, VDD has been discovered to be associated with higher hazard for the metabolic syndrome and insulin resistance. ${ }^{31}$ In a research that involved postmenopausal females, the levels of fasting glucose were observed to be negatively related to serum $[25(\mathrm{OH}) \mathrm{D} 3] .{ }^{32}$

One of the new studies indicated that vitamin D levels could have inverse association to the levels of glycosylated hemoglobin in gestational diabetes mellitus. ${ }^{33}$ Moreover, it was proposed that sufficient vitamin D intake could be related with lower risks of developing gestational diabetes mellitus. ${ }^{34}$

In this research, lower levels of $1,25(\mathrm{OH})_{2} \mathrm{D} 3$ were recorded in individuals who had T2DM compared to controls, which can be attributed the consideration that the receptors of vitamin $\mathrm{D}$ were discovered in pancreatic beta cells, which, in addition were discovered for expressing the enzyme 1- $\alpha$-hydroxylase. ${ }^{35}$ Vitamin D facilitates insulin secretion from pancreatic $\beta$-cells, which is why it appears to control the insulin secretion. ${ }^{36}$ Therefore, VDD could be related with reduced insulin secretion in T2DM in addition to that, as vitamin D promotes insulin receptor expression, ${ }^{37} \mathrm{VDD}$ could be associated with $\mathrm{IR}^{38}$

According to those results it would be physiologically suitable recommending supplementation of vitamin $\mathrm{D}$ for the sake of improving glucose control in patients with T2DM. ${ }^{39}$ In accordance with that, vitamin D was administered to T2DM patients. ${ }^{40}$ Nevertheless, those researches didn't show steady results. In some of the researches supplementations of vitamin $\mathrm{D}$ were discovered to enhance glucose regulation in T2DM, ${ }^{39}$ while in others no such effect was observed. ${ }^{41}$ In a randomized controlled trial, administrating 2000 international units (IU) cholecalciferol each day for a period of 16 weeks has been discovered to enhance the function of beta cells in adults at high diabetes risks. ${ }^{42}$ Moreover, vitamin D was administered to diabetics of type 2 with nephropathy and has been discovered to ameliorate albuminuria. ${ }^{43}$ At a molecular level, vitamin D seems to have an impact on reducing oxidative stress. ${ }^{44}$

This research has a number of obstacles. Due to the fact that it's an observational research, it means that conclusion cannot be made whenever any cause and effect association is concerned between T2DM and VDD. Moreover, 1,25(OH) 2 D3 has been selected as a marker for VDD, as presently suggested. Nevertheless, vitamin D circulates in the blood in different forms and the active form of this vitamin is $1,25(\mathrm{OH})_{2} \mathrm{D} 3$. Therefore, a larger number of researches are required utilizing finer tools for determining the VDD in humans and particularly, in diabetes patients. A larger number of researches are as well required with supplementation of vitamin D and glucose control long-term observation in T2DM.

After discussing those results, the hidden correlation between VDD and a variety of diseases is still to be discovered. ${ }^{45}$ Vitamin D could be associated with autoimmunity in addition to metabolic diseases. ${ }^{46}$ Moreover, recent research was set forward, it is concerned with discussing the correlation between vitamin $\mathrm{D}$ and adipose tissue. It seems that vitamin $\mathrm{D}$ could influence adipogenesis, ${ }^{47,48}$ thereby it modulates energy consumption in adipose tissue. Those innovative discoveries could give an explanation to the reason why vitamin D administration to diabetes mellitus patients and the metabolic syndrome patients seems to have contradictory effects.

The results that have been presented in this study are of therapeutic implications. In T2DM patients, normal vitamin D levels in the blood could facilitate regulation of glucose. Moreover, in individuals that tend to develop T2DM, the optimum vitamin $\mathrm{D}$ levels in the blood could delay the clinical development of T2DM. 


\section{Conclusions}

VDD is associated to the risk of experiencing T2DM. Hypovitaminosis D is very prevalent among the study participants and its percent was higher in female and patients than this in male and controls, respectively. Those results could have therapeutic implications as cautious supplementation of vitamin D could enhance glycemic control in T2DM.

\section{References}

1. Hadi, SM, Al-Tu'ma, FJ, and Al-Zubaidi, RD. Genotyping of Vitamin D Receptor FOKI Polymorphism as a predictor for Type 2 diabetes Mellitus by a Tetra primer-ARMS-PCR Assay. Gene Rep. (2019):15:100365

2. Zisser H, Gong P, Kelley CM, Seidman JS, Riddell MC. Exercise and diabetes. Int J Clin Pract Suppl. 2011;170:71-5.

3. Prokopenko I, McCarthy MI, Lindgren CM. Type 2 diabetes: New genes, new understanding. Trends Genet. 2008:24:613-21.

4. Pilz S, Tomaschitz A, Ritz E, Pieber TR. Vitamin D status and arterial hypertension: a systematic review. Nat Rev Cardiol. 2009 Oct;6(10): $621-30$

5. Wang TJ, Pencina MJ, Booth SL, Jacques PF, Ingelsson E, Lanier K, et al. Vitamin D deficiency and risk of cardiovascular disease. Circulation. 2008 Jan 29;117(4):503-11.

6. Targher G, Bertolini L, Padovani R, Zenari L, Scala L, Cigolini M, et al. Serum 25-hydroxyvitamin $\mathrm{D}_{3}$ concentrations and carotid artery intima-media thickness among type 2 diabetic patients. Clin Endocrinol (Oxf). 2006 Nov;65(5):593-97.

7. Demay MB, Kiernan MS, DeLuca HF, Kronenberg HM. Sequences in the human parathyroid hormone gene that bind the 1,25-dihydroxy vitamin D3 receptor and mediate transcriptional repression in response to 1,25-dihydroxy vitamin D3. Proc Natl Acad Sci USA. 1992;89:8097-101.

8. Al-Tu'ma, FJ, and Yosuf, LMZ. Vitamin D deficiency and hypertension in type 2 diabetic Iraqi patients. J Contemp Med Sci., 2015;1(1):17-20.

9. Melamed, ML, Michos, ED, Post, W, and Astor, B. 25-hydroxyvitamin D levels and the risk of mortality in the general population. Arch Intern Med, 2008;168(15):1629-37.

10. Palomer, X, González-Clemente, JM, Blanco-Vaca, F, and Mauricio, D. Role of vitamin $D$ in the pathogenesis of type 2 diabetes mellitus. Diab Obesity Metab, 2008;10(3):185-197.

11. Martin, T, and Campbell, RK. 2011. Vitamin D and diabetes. Diab Spect, 2011;24(2):113-118

12. Reis AF, Hauache OM, Velho G. Vitamin D endocrine system and the genetic susceptibility to diabetes, obesity and vascular disease. A review of evidence. Diab Metab. 2005:31:318-25.

13. Lips, P, Eekhoff, M, van Schoor, N, Oosterwerff, M, de Jongh, R, Krul-Poel, Y, and Simsek, S. Vitamin D and type 2 diabetes. J Steroid Biochem Mol Biol, 2016:173:280-285.

14. Nakashima, A, Yokoyama, K, Yokoo, T, and Urashima, M. Role of vitamin D in diabetes mellitus and chronic kidney disease. World J Diab, 2016;7(5): $89-100$

15. Al-Tu'ma, FJ, Mohammed, AM, and Al-Saraf, HH. Role of Vitamin D3 and Apo-B/ApoA-1 ratio in patients with unstable angina in Kerbala Province: Iraq. J Contemp Med Sci, 2017:3(10):224-28.

16. Rahi, SAZ, Al-Tu'ma, FJ, Al-Ganabi, AM and Al-Tu'ma, J.F. Polymorphism of Vitamin D receptor (re2228570) in sera of coronary artery diseases and biochemical parameters. Al-Qadisiyah Med J 2018;14(25):1-8.

17. Rosen, C, Adams, J, Bikle, D, Black, D, Demay, M, Manson, J. et al. The nonskeletal effects of vitamin D: An Endocrine Society scientific statement. Endocr Rev, 2012;33:456-492

18. Weiss, S. Bacterial components plus vitamin D: The ultimate solution to the asthma (autoimmune disease) epidemic? J Allergy Clin Immunol, 2011:127:1128-1130

19. Weinstock-Guttman, B, Mehta, B, Ramanathan, M, Karmon, Y, Henson, L, Halper, J. et al. Vitamin D and multiple sclerosis. Neurologist, 2012;18: $179-183$.

20. Haga, H., Schmedes, A., Naderi, Y., Moreno, A. and Peen, E. Severe deficiency of 25 -hydroxyvitamin $\mathrm{D}(3)(25(\mathrm{OH}) \mathrm{D} 3)$ is associated with high disease activity of rheumatoid arthritis. Clin Rheumatol, 2013;32: 629-633.

21. Hyppönen, E., Lärä, E., Reunanen, A., Järvelin, M. and Virtanen, S. Intake of vitamin $D$ and risk of type 1 diabetes: A birth-cohort study. Lancet, 2001;358:1500-1503.
22. Maxwell, C. and Wood, R. Update on vitamin D and type 2 diabetes. Nut Rev, 2011:69:291-295.

23. Lim, S., Kim, M., Choi, S., Shin, C., Park, K., Jang, H. et al. Association of VDD with incidence of type 2 diabetes in high-risk Asian subjects. Am J Clin Nutr. 2013:97:524-530

24. Hurskainen, A, Virtanen, J, Tuomainen, T, Nurmi, T, and Voutilainen, S. Association of serum 25-hydroxyvitamin D with type 2 diabetes and markers of insulin resistance in a general older population in Finland. Diab Metab Res Rev 2012;28:418-423.

25. Heaney, R, French, C, Nguyen, S, Ferreira, M, Baggerly, L, Brunel, L. et al. A novel approach localizes the association of vitamin D status with insulin resistance to one region of the 25 -hydroxyvitamin D continuum. Adv Nutr 2013;4:303-310.

26. Pittas, A, Sun, Q, Manson, J, Dawson-Hughes, B. and Hu, F. Plasma 25-hydroxyvitamin $\mathrm{D}$ concentration and risk of incident type 2 diabetes in women. Diab Care, 2010;33:2021-2023.

27. Pittas, A, Nelson, J, Mitri, J, Hillmann, W, Garganta, C, Nathan, D. et al. Plasma 25-hydroxyvitamin D and progression to diabetes in patients at risk for diabetes: An ancillary analysis in the Diabetes Prevention Program. Diab Care, 2012:35:565-573.

28. Schöttker, B, Herder, C, Rothenbacher, D, Perna, L, Müller, H, and Brenner, H. Serum 25-hydroxyvitamin D levels and incident diabetes mellitus type 2: a competing risk analysis in a large population-based cohort of older adults. Eur J Epidemiol, 2013;28:267-275.

29. Liu, S, Song, Y, Ford, E, Manson, J, Buring, J, and Ridker, P. Dietary calcium, vitamin $D$, and the prevalence of metabolic syndrome in middle-aged and older U.S. women. Diab Care, 2005:28:2926-2932.

30. Pittas, A, Dawson-Hughes, B, Li, T, Van Dam, R, Willett, W, Manson, J. et al. Vitamin $\mathrm{D}$ and calcium intake in relation to type 2 diabetes in women. Diab Care, 2006;29:650-656.

31. Chiu, K, Chu, A, Go, V, and Saad, M. Hypovitaminosis D is associated with insulin resistance and beta cell dysfunction. Am J Clin Nutr, 2004;79: $820-825$.

32. Need, A, O'Loughlin, P, Horowitz, M, and Nordin, B. Relationship between fasting serum glucose, age, body mass index and serum 25 hydroxyvitamin D in postmenopausal women. Clin Endocrinol (Oxford), 2005;62: 738-741

33. Lau, S, Gunton, J, Athayde, N, Byth, K, and Cheung, N. Serum 25-hydroxyvitamin D and glycated haemoglobin levels in women with gestational diabetes mellitus. Med J Aust, 2011;194:334-337.

34. Alzaim, M, and Wood, R. Vitamin D and gestational diabetes mellitus. Nutr Rev, 2013; 71:158-167.

35. Bland, R, Markovic, D, Hills, C, Hughes, S, Chan, S, Squires, P. et al. Expression of 25-hydroxyvitamin D3-1alpha-hydroxylase in pancreatic islets. J Steroid Biochem Mol Biol 2004:89-90:121-125.

36. Zeitz, U, Weber, K, Soegiarto, D, Wolf, E, Balling, R, and Erben, R. Impaired insulin secretory capacity in mice lacking a functional vitamin $D$ receptor. FASEB J 2003;17:509-511.

37. Maestro, B, Campión, J, Dávila, N, and Calle, C. Stimulation by 1,25-dihydroxyvitamin D3 of insulin receptor expression and insulin responsiveness for glucose transport in U-937 human promonocytic cells. Endocr J 2000;47:383-391.

38. Talaei, A, Mohamadi, M, and Adgi, Z. The effect of vitamin D on insulin resistance in patients with type 2 diabetes. Diabetol Metab Syndr, 2013; $5: 8$

39. Osei, K. 25-OH vitamin D: is it the universal panacea for metabolic syndrome and type 2 diabetes? J Clin Endocrinol Metab, 2010;95:4220-22.

40. Al-Daghri, N.M., Alkharfy, K.M., Al-Othman, A., El-Kholie, E., Moharram, O., Alokail, M.S. et al. Vitamin D supplementation as an adjuvant therapy for patients with T2DM: An 18-month prospective interventional study. Cardiovasc Diabetol, 2012;11:85.

41. Heshmat, R, Tabatabaei-Malazy, O, Abbaszadeh-Ahranjani, S, Shahbazi, S, Khooshehchin, G, Bandarian, F. et al. Effect of vitamin D on insulin resistance and anthropometric parameters in Type 2 diabetes: A randomized doubleblind clinical trial. Daru 2012:20:10.

42. Mitri, J, Dawson-Hughes, B, Hu, F, and Pittas, A. Effects of vitamin D and calcium supplementation on pancreatic $\beta$ cell function, insulin sensitivity, and glycemia in adults at high risk of diabetes: The Calcium and Vitamin D for Diabetes Mellitus (CaDDM) randomized controlled trial. Am J Clin Nutr, 2011:94:486-494.

43. Huang, Y, Yu, H, Lu, J, Guo, K, Zhang, L, Bao, Y. et al. Oral supplementation with cholecalciferol $800 \mathrm{IU}$ ameliorates albuminuria in Chinese type 2 diabetic patients with nephropathy. PLoS One, 2012;7:e50510.

44. Salum, E, Kals, J, Kampus, P, Salum, T, Zilmer, K, Aunapuu, M. et al. Vitamin $D$ reduces deposition of advanced glycation end- products in the aortic 
wall and systemic oxidative stress in diabetic rats. Diab Res Clin Pract 2013:100:243-249.

45. Chagas, C, Borges, M, Martini, L, and Rogero, M. Focus on vitamin D, inflammation and type 2 diabetes. Nutrients 2012;4:52-67.

46. Holick, M. Evidence-based D-bate on health benefits of vitamin D revisited. Dermatoendocrinology, 2012;4:183-190.
47. Ochs-Balcom, H, Chennamaneni, R, Millen, A, Shields, P, Marian, C, Trevisan, $M$. et al. Vitamin $D$ receptor gene polymorphisms are associated with adiposity phenotypes. Am J Clin Nutr, 2011;93:5-10.

48. Landrier, J, Marcotorchino, J, and Tourniaire, F. Lipophilic micronutrients and adipose tissue biology. Nutrients, 2012;4:1622-1649.

This work is licensed under a Creative Commons Attribution-NonCommercial 3.0 Unported License which allows users to read, copy, distribute and make derivative works for non-commercial purposes from the material, as long as the author of the original work is cited properly. 